\title{
FARMER BEHAVIOR TRANSFORMATION ON TOMATO FARMING BUSINESS IN MEGA MENDUNG SUBDISTRICT BOGOR, WEST JAVA
}

\author{
Dr. Lukman Effendy ${ }^{1)}$ \\ 1) Associate Professor Agricultural Extension \\ Sustainable Agricultural Extension Study Program \\ Bogor Agricultural Development Polytechnique \\ Jl. Aria Surialaga - Cibalagung Bogor \\ West Java, Indonesia \\ Email; f1515di@gmail.com \\ Wida Pradiana, M.Si ${ }^{2)}$ \\ ${ }^{2)}$ Lecturer Agricultural Extension \\ Sustainable Agricultural Extension Study Program \\ Bogor Agricultural Development Polytechnique \\ Jl. Aria Surialaga - Cibalagung Bogor \\ West Java, Indonesia \\ Dr. Yoyon Haryanto ${ }^{3)}$ \\ ${ }^{3)}$ Lecturer Agricultural Extension \\ Sustainable Agricultural Extension Study Program \\ Bogor Agricultural Development Polytechnique \\ Jl. Aria Surialaga - Cibalagung Bogor \\ West Java, Indonesia \\ Tedo Harischandra ${ }^{2)}$ \\ 4) Post Graduate Student \\ Sustainable Agricultural Extension Study Program \\ Bogor Agricultural Development Polytechnique \\ Jl. Aria Surialaga - Cibalagung Bogor \\ West Java, Indonesia \\ Email; tedoharis@outlook.com
}

DOI: 10.31364/SCIRJ/v8.i8.2020.P0820799

http://dx.doi.org/10.31364/SCIRJ/v8.i8.2020.P0820799

\begin{abstract}
The tomato farmer behavior transformation from subsystem to commercial is expected to obtain a culture technique that can finally improve the farmer livelihood and welfare. Thereby, this study was aimed to: (1) describe the behavior transformation happened on tomato farming business in Mega Mendung Subdistrict, (2) analyze the factors that influenced the farmer behavior transformation in tomato farming business, and (3) formulate a model or strategy to accelerate the tomato farmer behavior transformation. The survey study involved 100 respondents from 150 vegetable farmers using a simple sampling technique (Simple Random Sampling). Data collection was performed through direct interview using a closed-questionnaire which has been tested its validity and reliability before used as data collection instrument. The data obtained were analyzed using descriptive statistical and path analysis. The result showed that: (1) farmer behavior in the tomato farming application was included in a moderate category, therefore necessary to be improved, (2) factors influencing the behavior transformation such as: (a) business climate $\left(\mathrm{X}_{3}\right)$, farmer perception on extension $\left(\mathrm{X}_{4}\right)$, and innovation characteristics $\left(\mathrm{X}_{5}\right)$, directly and significantly influenced $(\mathrm{p}<$ $0.05)$ the farmer behavior transformation, while the internal characteristics $\left(\mathrm{X}_{2}\right)$ and communication behavior $\left(\mathrm{X}_{2}\right)$ influenced insignificantly $(\mathrm{p}>0.05)$.
\end{abstract}

Keywords; 1.Transformation, 2. Farmer Behavior, 3. Tomato Farming, 4. Path Analysis 


\section{INTRODUCTION}

Agricultural sector is one sector that still performs during the Covid-19 pandemic, while some sectors are affected even postponed their activities. The development in this sector is still ongoing as the Indonesian Ministry of Agriculture Affairs in the end of 2019 has released ten main programs as the efforts to improve agricultural productivity and commodity export. One of these ten programs is Gedorhorti, which is an application of horticulture commodity production movement including vegetables as one of which is tomato plant. Tomato is included in a high economical value commodity, however as the same as other fruits and vegetables, tomato is perishable with a relatively shorter time of preservation period than the usual preservation method, thus influencing the tomato freshness level. The shrinkage post-harvest of tomato fruit in Indonesia reaches 20-50\% (Prajawati, 2006). Reminding that tomato is included in a perishable commodity, transportation process and risk deprivation need to be improved.

As a vegetable fruit, tomato has its own attraction due to a stunning fruit color, capable of freshly eaten, easy to culture, making the farmers attracted to conduct a tomato farming business. Tomato plant is relatively easy to be cultured as capable of growing well in a high or lowland, however the obstacle in culturing tomato is vulnerable to bacterial withered disease (Ralstonia solanacearum), fungal withered disease (Fusarium ongysporum), and cotton bollworm larvae (Heliothis armigera). Thereby for farmers who will conduct a tomato farming business, they should have a sufficient technical knowledge about tomato culture starting from seed and seedling selection, tillage, plastic pulse usage, stake setting, fertilization, plant pest maintenance, harvesting, harvesting result management, and marketing. However, not all farmers understand and apply a good and right tomato culture technique in the field as sometimes causing an unsuccessful tomato planting/harvesting failure due to disease attack caused by the lack of disease maintenance understanding. This condition happens as the culture technical knowledge is mostly retrieved from a passed-down experience which was inherited by their parents, following the study result of Effendy, Kusnadi, Maryani, and Pradiana (2020) on chili farming business in Garut Regency who stated that youngsters who conducted chili farming business was based on experience and their parents. Meanwhile to reach a high success, it is necessary to have an improved knowledge, skill, and behavior or in other words are behavior transformation in culturing and conducting a tomato farming business by following the technological suggestion or recommendation as Amanah (2007) stated that the behavioral aspects expected to transform contained thinking pattern, acting pattern, and character whenever facing a livelihood transformation.

Based on the explanation above, a study was performed in some villages of Megamendung Subdistrict as one of tomato producing regions that is quite important in Bogor Regency supported with land potential area, climate, and community behavior to conduct a farming business. Nevertheless, an efficiency aspect needs more attention; therefore the costs spent during the production are balanced with the income obtained after harvesting. Whenever there is less attention on business efficiency in the production activity, it is possible for tomato farmer to gain a profitable result. From the following factors, it is known that the farming business application can increase the farmer behavior transformation in improving the knowledgement as well as the result obtained by utilizing an available information facility existed on this era, as easier access granted will impact on an easier innovation to be applied in a business, especially tomato farming business. This study was specifically aimed to: (1) describe the behavior transformation happened on tomato farming business in Mega Mendung District, (2) analyze the factors that influenced the farmer behavior transformation in tomato farming business, and (3) formulate a model or strategy to accelerate the tomato farmer behavior transformation.

\section{Thinking Framework}

Farmer behavior transformation can be determined through some factors either from internal or external. Some variables suspectively influence the transformation process of farmer behavior in tomato farming business, namely the independent factors contain: $\left(\mathrm{X}_{1}\right)$ farmer characteristics, $\left(\mathrm{X}_{2}\right)$ communication behavior, $\left(\mathrm{X}_{3}\right)$ farming business environment, $\left(\mathrm{X}_{4}\right)$ farmer perception-extension, $\left(\mathrm{X}_{5}\right)$ innovation characteristics, and dependent factor contains tomato farming business behavior (Y). These factors partially or simultaneously influence the behavior transformation which can schematically presented below:

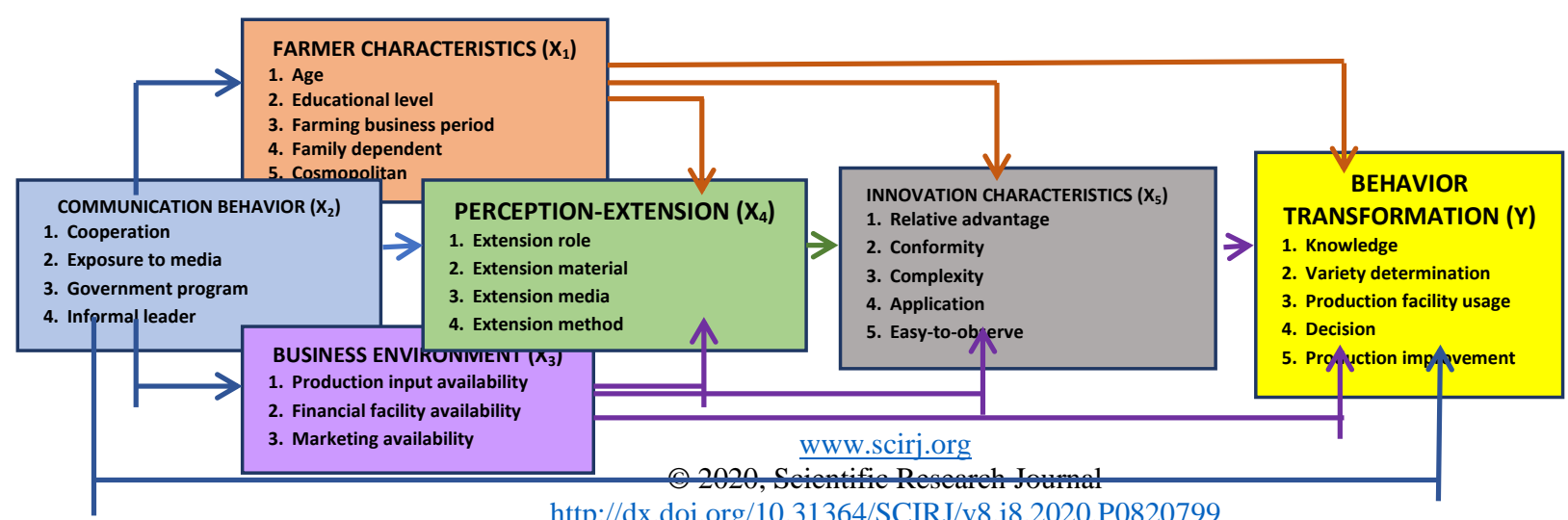


Figure 1. Farmer behavior transformation thinking framework

\section{METHODS}

Based on its aim, this study was an explanation study type, while based on the data collection technique, this study was included in a survey study. The study was performed for 3 months (March - June, 2020) in Sukaresmi Village, Sukamanah, and Cipayung Village, Megamendung Subdistrict, Bogor Regency. The villages were selected based on land potential, climate, and land typology, as well as community interests in the vegetable farming business, especially tomato. The study population was farmer group members who performed a tomato farming business and applied a business analysis based on the suggestion and recommendation of local extension officers.

Based the following criteria, there were four farming groups spreaded in three selected villages with total of 150 people. From this population, 100 farmers were decided as the study respondents using a Slovin formula (Umar 2001) with the tolerated error (ê) was 6 percent (0.06). The instrument used was a closed-questionnaire containing questions and available answers. Before being used as a data collection instrument, this questionnaire was tested its validity and reliability. Based on the Cronbachalpha value, this questionnaire was eligible as data collection instrument.
Data collected were in the form of primary data obtained from a direct interview with the respondents and secondary data documented from the reports and extension program of Ciawi Agricultural Extension Center Region VII, as well as the local village monographics and other documents. To describe the study and farmer behavior variable performance, data were analyzed with descriptive statistics, while to find the factors that influenced the farmer transformation on tomato farming business, a pathanalysis was performed with the following model of $\overline{\mathrm{Y}}=$ $\rho y_{1} X_{1}+\rho y_{1} X_{2}+\rho y_{1} X_{3}+\rho y_{1} X_{4}+\rho y_{1} X_{5}+\rho y_{1} \varepsilon_{1}$. These data analysis used Microsoft Excel 2010 and Statistical Package for the Social Sciences (SPSS) 23.0.

\section{RESULT AND DISCUSSION}

\section{Result}

\subsection{Farmer Characteristic Description}

Individual characteristics are distinct individual characteristics that are different in one person to another. The respondent characteristics explained in this study contained: Age, educational level, farming land area, and family dependence. These respondent characteristics are presented on the following figure:

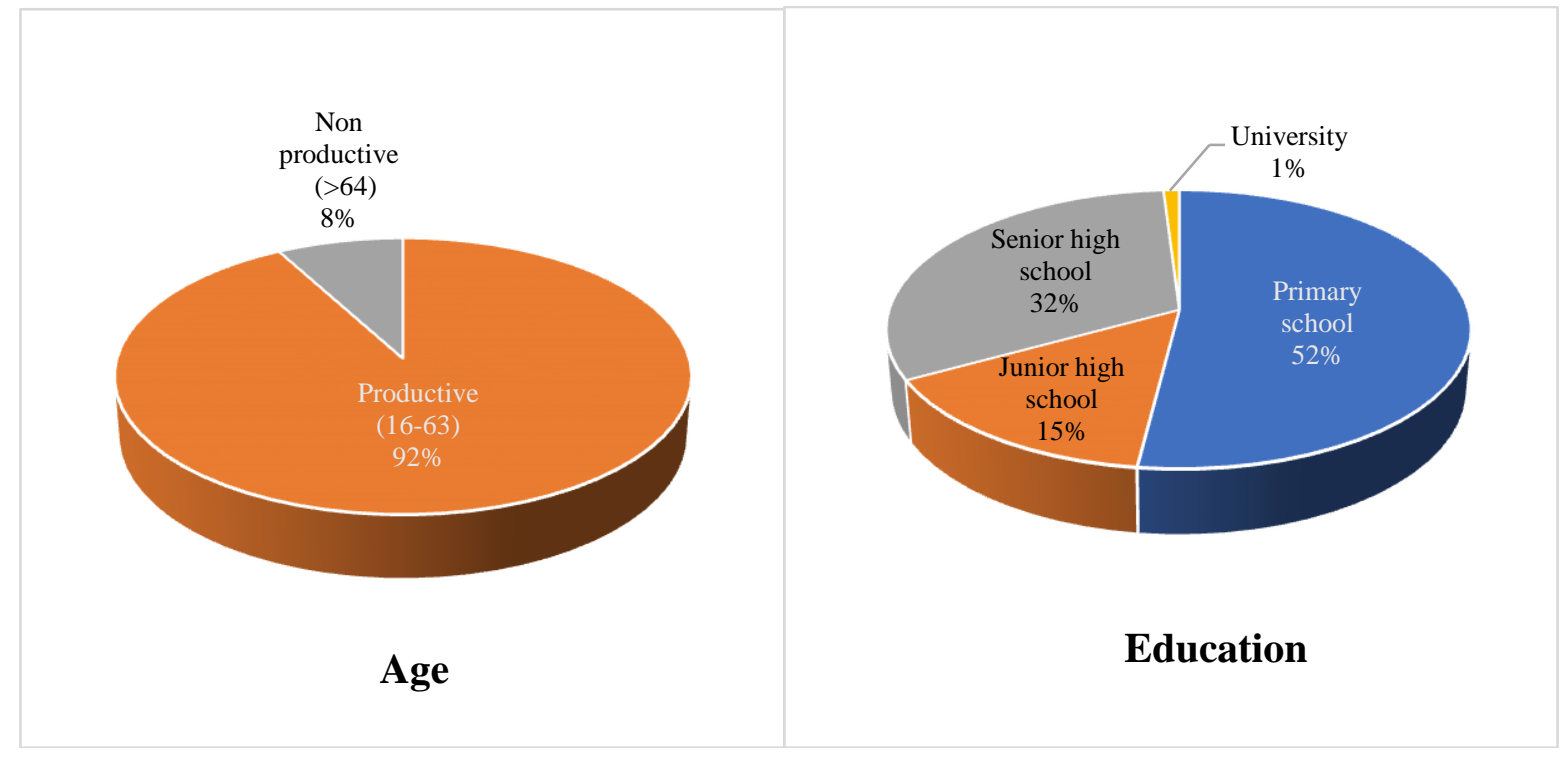

Figure 2a. Respondent Characteristic Performance 


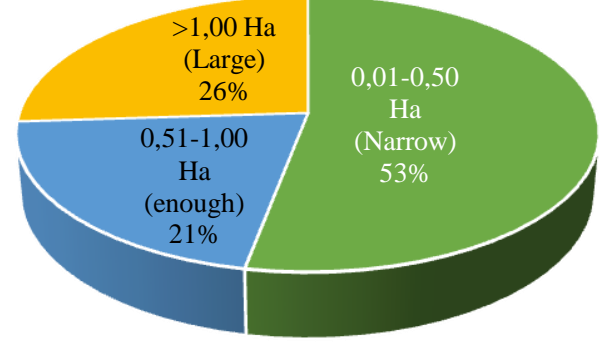

Farming land area

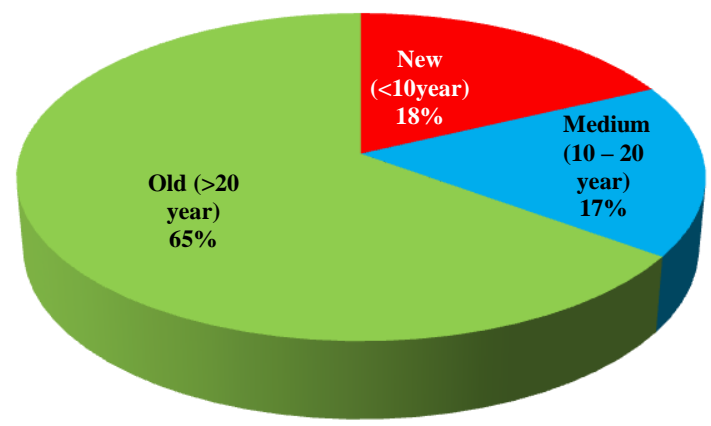

Farming Experience

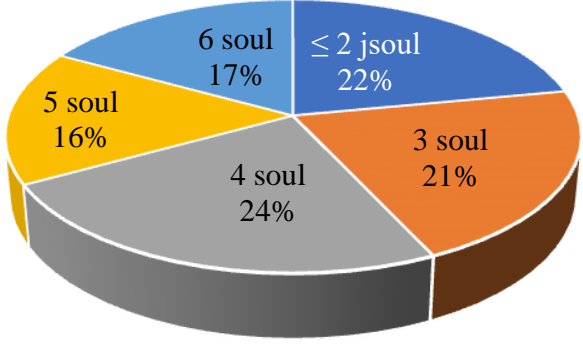

Family dependent

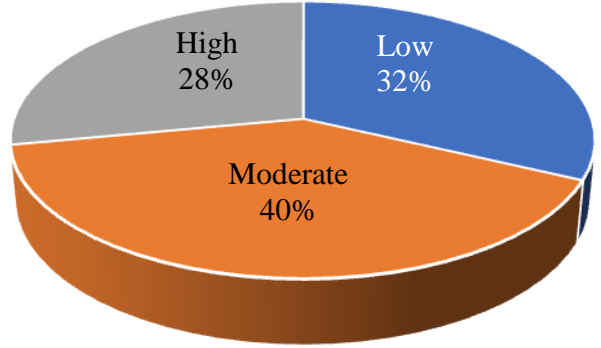

Cosmopolitan

Figure 2b. Respondent Characteristic Performance

The respondent characteristic performance (Figure 2a and $2 \mathrm{~b}$ ) presents that most respondents (92\%) are among $16-$ 63 years old. According to Mantra (2004), age group based on the productivity level and economical value, are divided into three categories, namely unproductive $(0-14$ years old $)$, productive $(15-64$ years old), and non-productive (> 65 years old) age. Furthermore, most respondents (52\%) have an educational level of primary school as based on the interview result, this condition happened due to the under-privileged family background condition, therefore having less chance to attend higher level education.

The major respondents $(53 \%)$ on the land ownership is categorized in a narrow land ownership, i.e 1,000-5,000 $\mathrm{m}^{2}$, with self-ownership status. Based on the respondent experience in tomato farming business, most respondents
$(65 \%)$ are included in a long-term category, i.e $3-55$ years. Meanwhile, based on the total family dependent, as much as $24 \%$ respondents have four people dependent. Moreover, the respondent cosmopolitan is included in a moderate category with $40 \%$.

\subsection{Communication Behavior Description}

Communication behavior is a way and habit to gain information as a farming business developmental effort. Communication behavior is measured based on the cooperation, exposure to media, government program, and local informal leader. The performance of respondent communication behavior is presented on Figure 3. 


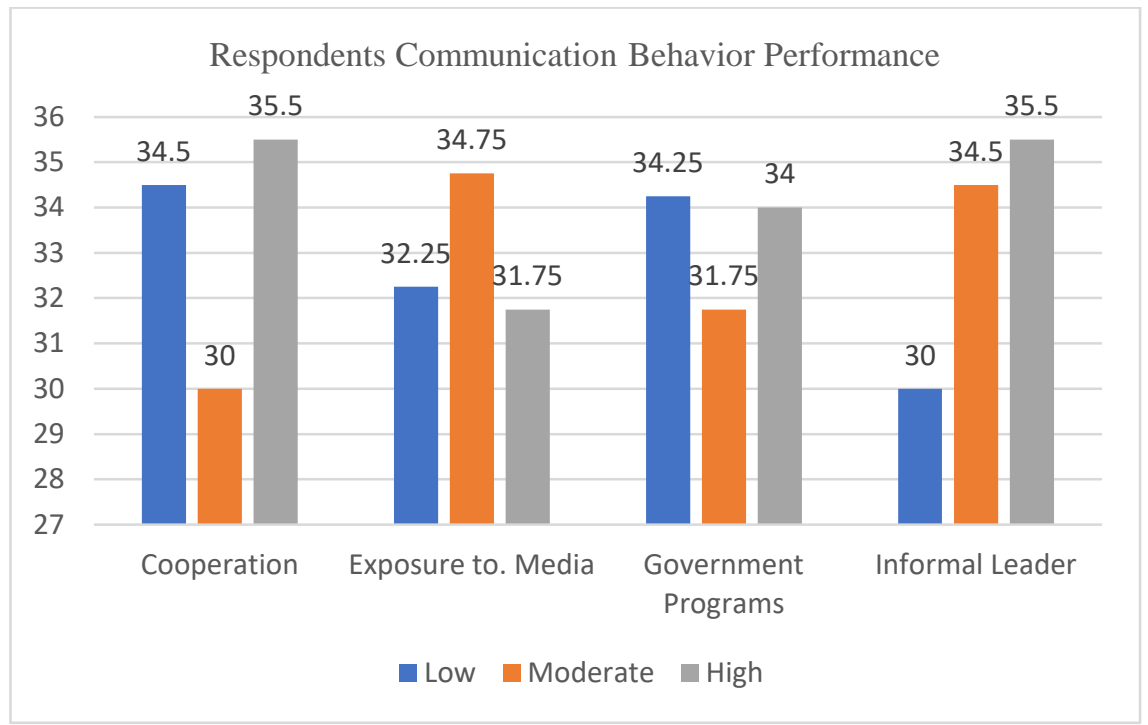

Figure 3.Respondent Communication Behavior Performance

Figure 3 explains that majority of behaviors (35.5\%) are included in cooperative with high category on the informal leader. Meanwhile, most communication behaviors $(34.75 \%)$ obtained from media are categorized as moderate. Communication behavior obtained from government program is categorized as low.
Business environment is an outer factor that triggers the behavior transformation of tomato farming business activity, containing production input availability, financial facility availability, and product marketing availability. The performance of environmental support is presented on Figure 4.

\subsection{Business Environment Description}

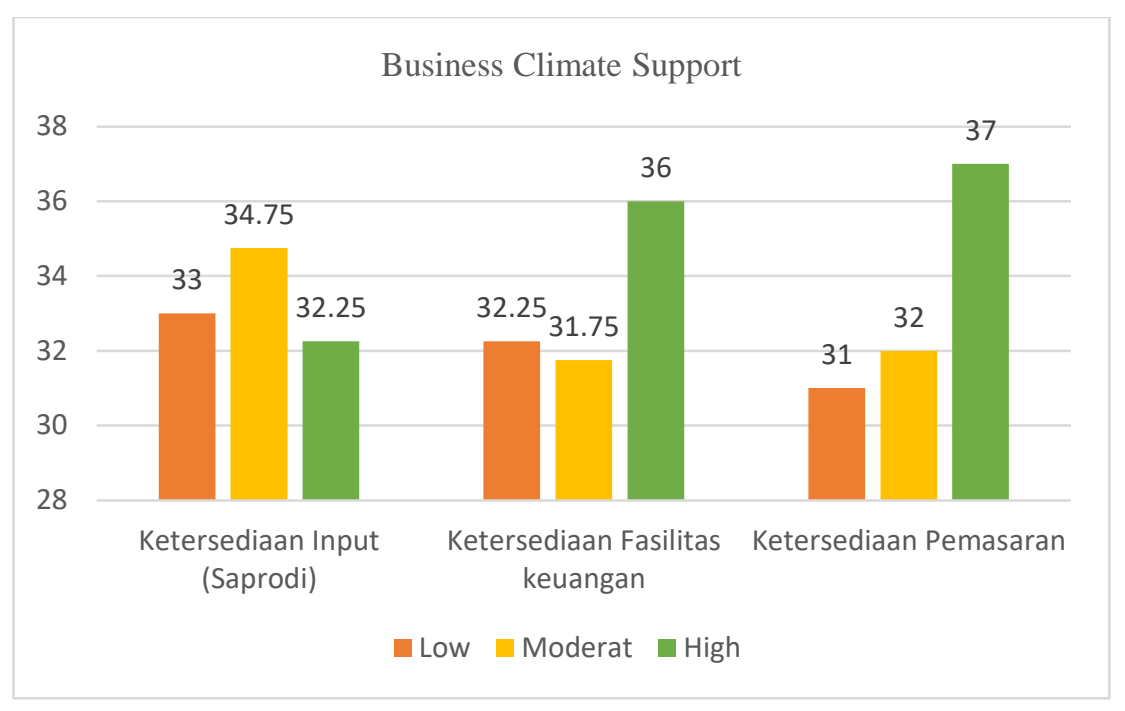

Figure 4. Business Climate Support

Figure 4 indicates that most respondents (37\%) admitted that marketing availability was included in a high category, besdies financial facility availability (36\%), while production input was included in a moderate category by most respondents.

\subsection{Farmer Perception on Extension Description}

Farmer perception on extension is a farmer understanding level on the extension program, containing extension officer role, material, media, and method. The performance of farmer perception on extension is presented on Figure 5. 


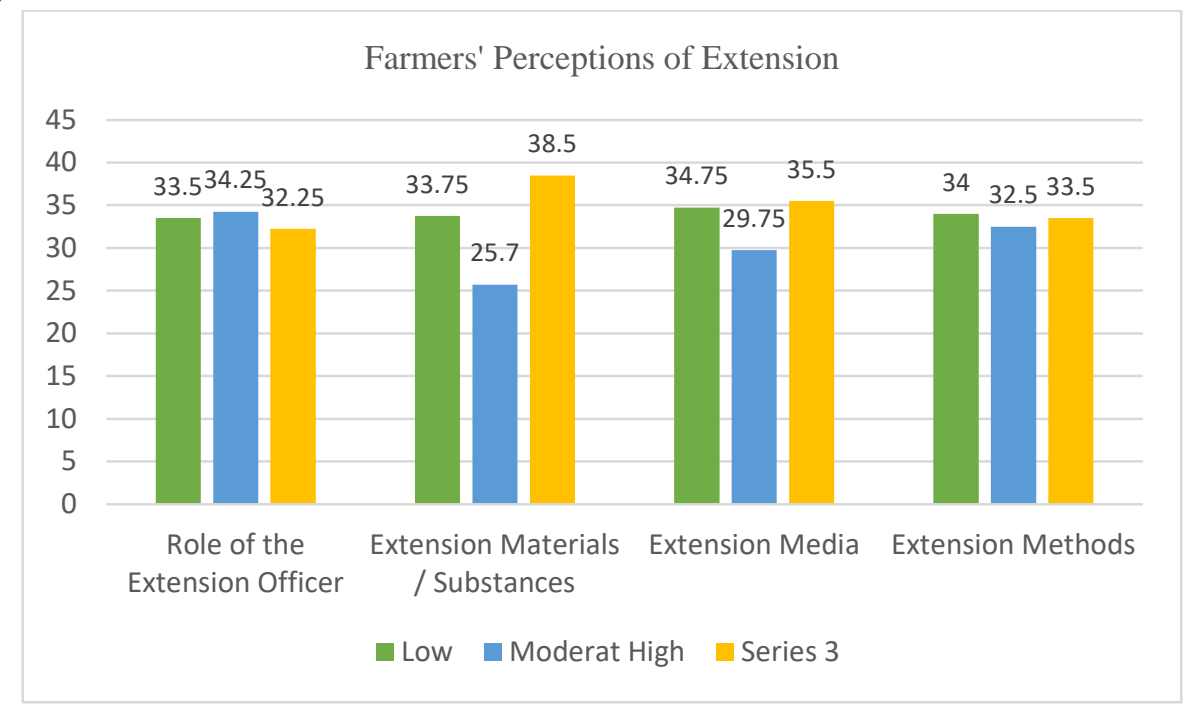

Figure 5. Farmer Perception on Extension

Figure 5 provides a hint that most respondents admitted on the extension material and media were included in high category. Moreover, the extension officer role was included in a moderate category, while extension method was included in a low category.

\subsection{Innovation Characteristic Description}

Innovation characteristic is the main character from an innovation containing relative advantage, conformity, complexity, easy to observe, and application. The performance of innovation characteristics is presented on Figure 6.

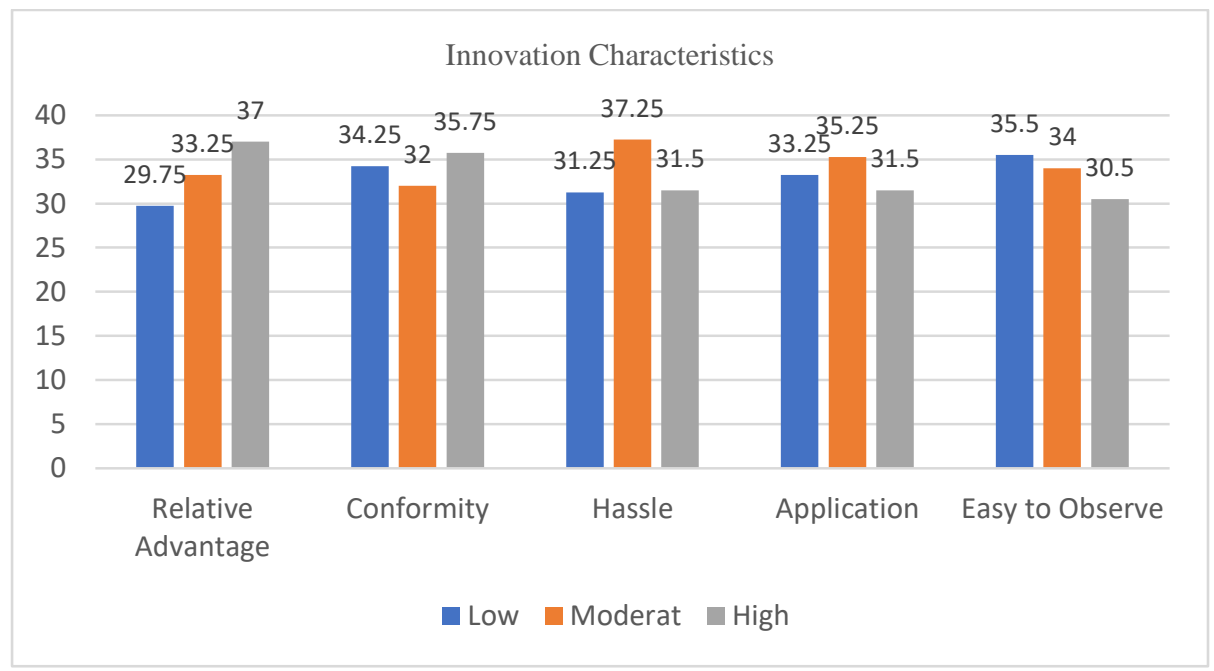

Gambar 6. Innovation Characteristic Level

Figure 6 provides an information that on the relative advantage and conformity, respondents admitted to be in a high category. About the complexity and application characteristic, respondents mostly perceived to be included in a moderate category, while easy-to-observe characteristic was included in a low category.

\subsection{Farmer Behavior on Tomato Farming Business}

The farmer behavior transformation on tomato farming business is measured from knowledge transformation, variety selection, production input usage, harvesting, harvesting result management, and decision. The following behavior transformation is presented on Figure 7. 


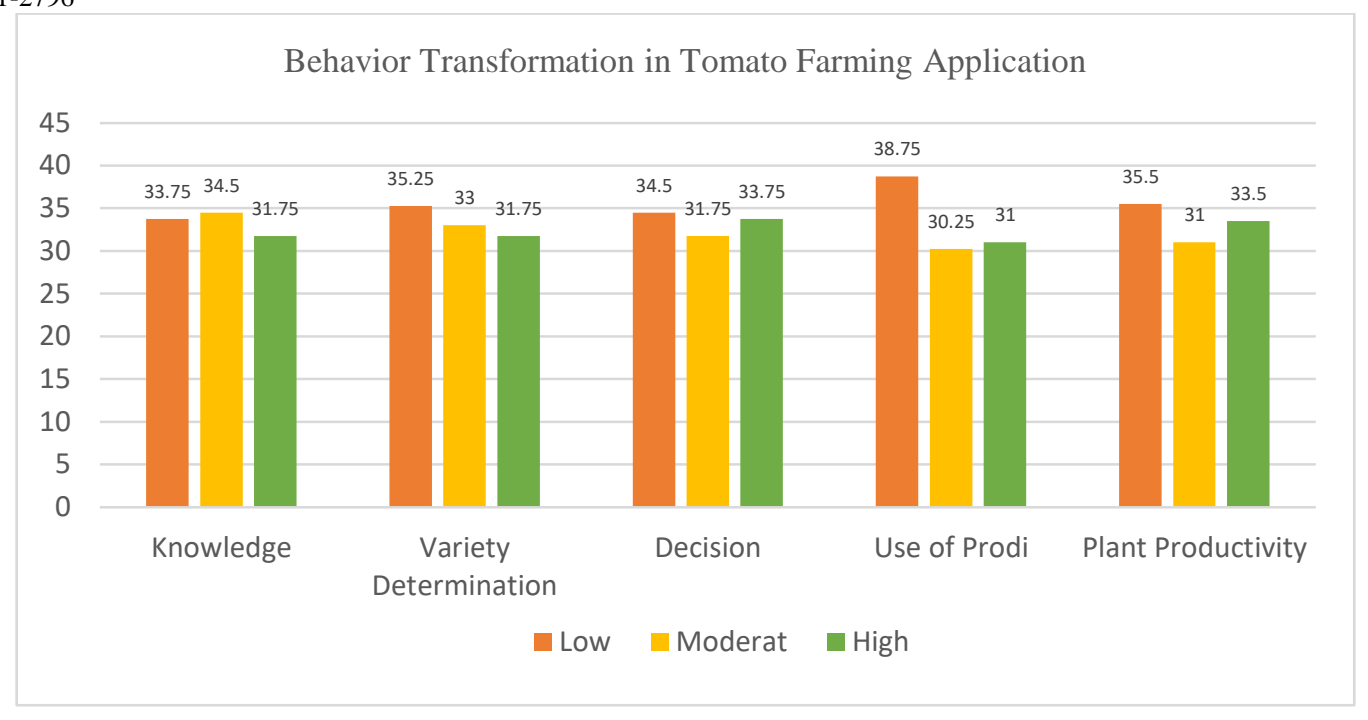

Figure 7. Farmer Behavior Transformation

Based on Figure 7, there are four aspects presented, namely production input usage, variety selection, productivity, and decision-making were admitted by the most respondents to be in a low category. Only on the knowledge transformation respondents admitted to be in a moderate category.

The regression analysis model 1 is used to identify the correlation strength from the independent variables (influencing variables) against the intervening variables. The structural equation becomes: farmer perception on extension $=$ $b_{1}$ farmer characteristics $+b_{2}$ communication behavior $+b_{3}$ business climate support $+\mathrm{e}_{1}$

\section{Factors Influencing the Behavior Transformation}

\subsection{Regression Analysis Model 1}

2.1.1. Individual Parameter Significance Test

The significance test aims to test the hypothesis by observing the significance value obtained. It is said to be significant if the significant value (sig.) Is smaller than 0.1 or 0.05 , and it can also be compared by comparing the t-hit value with the t-table, for the t-test model 1 (one) is presented in Table 1.

Table 1. Individual Parameter Significance Test (t-test) Model 1

\begin{tabular}{lccccc}
\hline \multicolumn{7}{c}{ Coefficient } \\
\hline \multirow{2}{*}{ Model } & \multicolumn{7}{c}{ Unstandardized Coefficients } & $\begin{array}{c}\text { Standardized } \\
\text { Coefficients }\end{array}$ & $\mathrm{t}$ & Sig. \\
\cline { 2 - 7 } & $B$ & Std. Error & Beta & & \\
\hline l(Constant) & 0.491 & 0.750 & & 1.652 & 0 \\
Farmer characteristics & 0.094 & 0.092 & 0.103 & 1.015 & 0.031 \\
Communication behavior & 0.144 & 0.096 & 0.094 & 0.411 & 0.055 \\
Business climate support & 0.128 & 0.104 & 0.093 & 0.314 & 0.049 \\
\hline
\end{tabular}

a. Independent Variable: Farmer perception on extension

Based on the SPSS test result on Table 1, the regression equation obtained is: $\mathrm{X}_{4}=0.491+0.094 \mathrm{X}_{1}+0.144 \mathrm{X}_{2}+-0.128$ $\mathrm{X}_{3}+\mathrm{e}_{1}$

Note:

$\mathrm{X}_{1} \quad=$ Farmer characteristics

$\mathrm{X}_{2} \quad=$ Communication behavior

$\mathrm{X}_{3} \quad=$ Business climate support

$\mathrm{X}_{4} \quad=$ Farmer perception on extension

$\mathrm{e}_{1} \quad=$ Error 
2.1.2. Determination coefficient $\left(\mathrm{R}^{2}\right)$

Determination coefficient is a value that shows how much the independent variable contribution against the dependent variable. The value of determination coefficient $\left(\mathrm{R}^{2}\right)$ model 1 is:

Table 2. Detemination Coefficient $\left(\mathbf{R}^{2}\right)$ Model I

\begin{tabular}{lcccc}
\hline \multicolumn{4}{c}{ Model Summary $^{\mathrm{b}}$} \\
\hline Model & $\mathrm{R}$ & $\mathrm{R}$ Square & Adjusted R Square & Std. Error of the Estimate \\
\hline 1 & $1.137^{\mathrm{a}}$ & 0.819 & 0.812 & 0.31173 \\
\hline a Predictors: & (Constant): Business Climate Support, Communication Behavior, Farmer Characteristics \\
b Independent Variable: Farmer perception on extension
\end{tabular}

The SPSS model summary analysis result indicates the number of $\mathrm{R}^{2}$ is 0.812 or in other words that $81.2 \%$ farmer perception on extension variable can be explained by the farmer characteristiscs, communication behavior, business climate support, while the rest $18.8 \%$ can be explained by other variables apart from this study.

characteristics $=b_{1}$ farmer characteristics $+b_{2}$ communication behavior $+b_{3}$ business climate support $+b_{4}$ farmer perception on extension $+\mathrm{e}_{2}$

2.2.1. Individual Parameter Significance Test

The significance test aims to test the hypothesis by observing the significance value obtained. It is said to be

\subsection{Regression Analysis Model 2}

The regression analysis model 2 is used to identify the correlation strength from the independent variables (influencing variables) against the intervening variables. The structural equation of model 2 is: Innovation significant if the significant value (sig.) Is smaller than 0.1 or 0.05 , and it can also be compared by comparing the t-hit value with the t-table, for the t-test model 2 (two) is presented in Table 3

Table 3. Individual Parameter Significance Test (t-test) Model 2

\begin{tabular}{|c|c|c|c|c|c|}
\hline \multicolumn{6}{|c|}{ Coefficients $^{\mathrm{a}}$} \\
\hline \multirow[b]{2}{*}{ Model } & \multicolumn{2}{|c|}{$\begin{array}{c}\text { Unstandardized } \\
\text { Coefficients }\end{array}$} & \multirow{2}{*}{$\begin{array}{c}\begin{array}{c}\text { Standardized } \\
\text { Coefficients }\end{array} \\
\text { Beta }\end{array}$} & \multirow[t]{2}{*}{$\mathrm{t}$} & \multirow[t]{2}{*}{ Sig. } \\
\hline & $\mathrm{B}$ & Std. Error & & & \\
\hline $1($ Constant $)$ & 0.634 & 0.102 & & 0.624 & 0 \\
\hline Farmer characteristics & 0.034 & 0.104 & 0.034 & 0.327 & 0.074 \\
\hline Communication behavior & 0.133 & 0.108 & 0.937 & 2.618 & 0.005 \\
\hline Business climate support & 0.175 & 0.118 & 0.078 & 1.216 & 0.008 \\
\hline Perception on extension & 0.181 & 0.115 & 0.835 & 1.165 & 0.008 \\
\hline
\end{tabular}

a. Independent Variable: Innovation characteristics

Based on the SPSS test result on Table 3, the regression equation indicating the variables in this study is $: X_{5}=0.634+0.034 X_{1}+0.133 X_{2}+0.175 X_{3}+-0.181 X_{4}$ $+\mathrm{e}_{2}$

\subsubsection{Determination Coefficient $\left(\mathrm{R}^{2}\right)$}

Determination coefficient is a value that shows how much the independent variable contribution against the dependent variable. The value of determination coefficient $\left(\mathrm{R}^{2}\right)$ model 2 is:

Table 4. Determination Coefficient $\left(\mathbf{R}^{2}\right)$ Model 2

\begin{tabular}{lcccc}
\hline \multicolumn{5}{c}{ Model Summary $^{\mathrm{b}}$} \\
\hline Model & $\mathrm{R}$ & $\mathrm{R}$ Square & Adjusted R Square & Std. Error of the Estimate \\
\hline 2 & $0.74 \mathrm{a}$ & 0.599 & 0.639 & 0.351315 \\
\hline a Predictors: & (Constant): Farmer Perception on Extension, Business Climate Support, \\
Communication Behavior, Farmer Characteristics \\
b Independent Variable: Innovation Characteristics
\end{tabular}


The SPSS model summary analysis result indicates the number of $\mathrm{R}^{2}$ is 0.639 or $63.9 \%$ innovation characteristics variable can be explained by the farmer characteristiscs, communication behavior, business climate support, farmer perception on extension, while the rest $36.1 \%$ can be explained by other variables apart from this study.

\subsubsection{Individual Parameter Significance Test}

The significance test aims to test the hypothesis by observing the significance value obtained. It is said to be significant if the significant value (sig.) Is smaller than 0.1

\subsection{Regression Analysis Model 3}

The regression analysis model 3 is used to identify the correlation strength from the independent variables (influencing variables) against the dependent variables (influenced variables). The structural equation of model 3 is: Farmer Behavior Transformation $=b_{1}$ farmer characteristics $+b_{2}$ communication behavior $+b_{3}$ business climate support $+b_{4}$ farmer perception on extension $+b_{5}$ innovation characteristics $+\mathrm{e}_{3}$

or 0.05 , and it can also be compared by comparing the t-hit value with the t-table, for the t-test model 3 (three) is presented in Table 5.

Table 5. Individual Parameter Significance Test (t-test) Model 3

\begin{tabular}{lccccc}
\hline \multicolumn{1}{c}{ Coefficients $^{\mathrm{a}}$} & & \\
\hline \multicolumn{1}{c}{ Model } & \multicolumn{2}{c}{$\begin{array}{c}\text { Unstandardized } \\
\text { Coefficients }\end{array}$} & $\begin{array}{c}\text { Standardized } \\
\text { Coefficients }\end{array}$ & $\mathrm{t}$ & Sig. \\
\cline { 2 - 6 } & $\mathrm{B}$ & Std. Error & Beta & & \\
\hline l(Constant) & 0.756 & 0.132 & & 0.585 & 0 \\
Farmer characteristics & -0.159 & 0.113 & -0.143 & -1.408 & 0.162 \\
Communication behavior & -0.103 & 0.117 & -0.089 & -0.880 & 0.381 \\
Business climate support & -0.081 & 0.127 & -0.065 & -0.635 & 0.052 \\
Perception on extension & 0.085 & 0.124 & 0,070 & 0,687 & 0.049 \\
Innovation characteristics & 0.049 & 0.111 & 0,045 & 0,446 & 0.034 \\
\hline
\end{tabular}

a. Dependent Variable: Farmer Behavior Transformation

Based on the SPSS test result on Table 3, the regression equation indicating the variables in this study is: $\mathrm{Y}_{1}=0.756+(-0.159) \mathrm{X}_{1}+(-0.103) \mathrm{X}_{2}+(-0.081) \mathrm{X}_{3}+$ $0.085 \mathrm{X}_{4}+0.049+\mathrm{e}_{3}$

\subsubsection{Determination Coefficient $\left(\mathrm{R}^{2}\right)$}

Determination coefficient is a value that shows how much the independent variable contribution against the dependent variable. The value of determination coefficient $\left(\mathrm{R}^{2}\right)$ model 3 is:

Table 6. Determination Coefficient $\left(\mathbf{R}^{2}\right)$ Model 3

\begin{tabular}{lcccc}
\hline \multicolumn{5}{c}{ Model Summary $^{\mathrm{b}}$} \\
\hline Model & $\mathrm{R}$ & $\mathrm{R}$ Square & Adjusted R Square & Std. Error of the Estimate \\
\hline 1 & $0.199^{\mathrm{a}}$ & 0.401 & 0.412 & 0.379121 \\
\hline \multicolumn{3}{l}{ a Predictors: } & (Constant): Innovation characteristics, Farmer Perception on Extension, Business \\
\multicolumn{3}{l}{ Climate Support, Communication Behavior, Farmer Characteristics } \\
b Dependent Variable: Farmer Behavior Transformation
\end{tabular}

The SPSS model summary analysis result indicates the number of $\mathrm{R}^{2}$ is 0.412 or $41.2 \%$. The farmer behavior transformation can be explained by the farmer characteristiscs, communication behavior, business climate support, farmer perception on extension, innovation characteristics, while the rest $58.8 \%$ can be explained by other variables apart from this study.

\section{Simultaneous Variable Influence on Behavior Transformation}

\subsection{Path analysis model interpretation}

The empirical causative influence among $\left(\mathrm{X}_{1}\right)$ farmer characteristics, $\left(\mathrm{X}_{2}\right)$ communication behvior, $\left(\mathrm{X}_{3}\right)$ business climate support, $\left(\mathrm{X}_{4}\right)$ farmer perception on extension, and $\left(\mathrm{X}_{5}\right)$ innovation characteristics variable against farmer 
behavior transformation $\left(\mathrm{Y}_{1}\right)$ variable can be drawn into three structural equations, namely: Farmer Behavior Transformation $=b_{1}$ farmer characteristics $\left(X_{1}\right)+b_{2}$ communication behavior $\left(\mathrm{X}_{2}\right)+\mathrm{b}_{3}$ business climate support The interpretation of path analysis result can be seen on the following Table 7:
$\left(X_{3}\right)+b_{4}$ farmer perception on extension $\left(X_{4}\right)+b_{5}$ innovation characteristics $\left(\mathrm{X}_{5}\right)+\mathrm{e}_{3}$ or Farmer Behavior Transformation $=0.756+-0.159 \mathrm{X}_{1}+(-0.103) \mathrm{X}_{2}+(-$ $0.081) \mathrm{X}_{2}+0.081 \mathrm{X}_{3}+0.085 \mathrm{X}_{4}+0.049+\mathrm{e}_{3}$.

Table 7. Summary of Model Parameter Estimation

\begin{tabular}{|c|c|c|c|c|}
\hline Model & $\begin{array}{l}\text { Unstandardized } \\
\text { coefficients beta }\end{array}$ & $T$ & Sig & $R^{2}$ \\
\hline \multicolumn{5}{|c|}{ Structural equation $1\left(\mathrm{X}_{1}, \mathrm{X}_{2}, \mathrm{X}_{3}\right.$ to $\left.\mathrm{X}_{4}\right)$} \\
\hline$X_{1}=P 1 X_{1} X_{4}$ & 0.094 & 1.015 & 0.031 & \multirow{3}{*}{$0 . .812$} \\
\hline $\mathrm{X}_{2}=\mathrm{P}_{2} \mathrm{X}_{2} \mathrm{X}_{4}$ & 0.144 & 0.411 & 0.055 & \\
\hline $\mathrm{X}_{3}=\mathrm{P}_{3} \mathrm{X}_{3} \mathrm{X}_{4}$ & 0.128 & 0.314 & 0.049 & \\
\hline \multicolumn{5}{|c|}{ Structural equation $2\left(\mathrm{X}_{1}, \mathrm{X}_{2}, \mathrm{X}_{3}, \mathrm{X}_{4}\right.$ to $\left.\mathrm{X}_{5}\right)$} \\
\hline $\mathrm{X}_{1}=\mathrm{P}_{4} \mathrm{X}_{1} \mathrm{X}_{5}$ & 0.034 & 0.327 & 0.074 & \multirow{4}{*}{0.639} \\
\hline $\mathrm{X}_{2}=\mathrm{P}_{5} \mathrm{X}_{2} \mathrm{X}_{5}$ & 0.133 & 2.618 & 0.005 & \\
\hline$X_{3}=P_{6} X_{3} X_{5}$ & 0.175 & 1.216 & 0.008 & \\
\hline $\mathrm{X}_{4}=\mathrm{P}_{7} \mathrm{X}_{4} \mathrm{X}_{5}$ & 0.181 & 1.165 & 0.008 & \\
\hline \multicolumn{5}{|c|}{ Structural equation $3\left(\mathrm{X}_{1}, \mathrm{X}_{2}, \mathrm{X}_{3}, \mathrm{X}_{4}, \mathrm{X}_{5}\right.$ to $\left.\mathrm{Y}_{1}\right)$} \\
\hline $\mathrm{X}_{1}=\mathrm{P}_{8} \mathrm{X}_{1} \mathrm{Y}_{1}$ & -0.159 & -1.408 & 0.162 & \multirow{5}{*}{0.412} \\
\hline $\mathrm{X}_{2}=\mathrm{P}_{9} \mathrm{X}_{2} \mathrm{Y}_{1}$ & -0.103 & -0.880 & 0.381 & \\
\hline $\mathrm{X}_{3}=\mathrm{P}_{10} \mathrm{X}_{3} \mathrm{Y}_{1}$ & -0.081 & -0.635 & 0.052 & \\
\hline $\mathrm{X}_{4}=\mathrm{P}_{11} \mathrm{X}_{4} \mathrm{Y}_{1}$ & 0.085 & 0.687 & 0.049 & \\
\hline $\mathrm{X}_{5}=\mathrm{P}_{12} \mathrm{X}_{5} \mathrm{Y}_{1}$ & 0.049 & 0.446 & 0.034 & \\
\hline
\end{tabular}

\subsection{Direct and Indirect Influence on Farmer Behavior Transformation}

Based on Table 7, it can be explained that there are direct and indirect influences of exogenous variables against endogenous variables.

3.2.1. Farmer characteristics influence on farmer behavior transformation

- Direct influence $\left(\mathrm{X}_{1} \mathrm{Y}_{1}\right)=-0.159$

- Indirect influence (through innovation characteristics $): \mathrm{X}_{1} \mathrm{X}_{5}=(0.094) \times(0.085)=$ 0.00799

- Indirect influence (through farmer perception on extension): $\mathrm{X}_{1} \mathrm{X}_{4}=(0.094)(0.049)=$ 0.004606

- When there is a greater indirect influence than direct influence, it can be concluded that the actual correlation is indirect or becomes an intervening variable.

3.2.2. Communication behavior influence on farmer behavior transformation

- Direct influence $\left(\mathrm{X}_{2} \mathrm{Y}_{1}\right)=-0.103$
- Indirect influence (through innovation characteristics $): \mathrm{X}_{2} \mathrm{X}_{5}=(0.144) \times(0.085)=$ 0.01224

- Indirect influence (through farmer perception on extension): $\mathrm{X}_{2} \mathrm{X}_{4}=(0.144)(0.049)=$ 0.007056

- When there is a greater indirect influence than direct influence, it can be concluded that the actual correlation is indirect or becomes an intervening variable.

3.2.3. Business climate support influence on farmer behavior transfomation

- Direct influence $\left(\mathrm{X}_{3} \mathrm{Y}_{1}\right)=-0.081$

- Indirect influence (through innovation characteristics $): \mathrm{X}_{3} \mathrm{X}_{5}=(0.128) \times(0.085)=$ 0.01088

- Indirect influence (through farmer perception on extension): $\mathrm{X}_{3} \mathrm{X}_{4}=(0.128) \times(0.049)=$ 0.006272

- When there is a greater indirect influence than direct influence, it can be concluded that the actual correlation is indirect or becomes an intervening variable. 
These influences can be concluded on Table 8 .

Table 8. Direct and Indirect Influence Analysis Result

\begin{tabular}{|c|c|c|c|c|c|c|}
\hline No & Variable & $\begin{array}{c}\text { Direc } \\
t\end{array}$ & Indirect & Total & Criteria & Conclusion \\
\hline 1 & $\begin{array}{l}\text { Farmer } \\
\text { Characteristics }\end{array}$ & $\begin{array}{c} \\
0.159 \\
- \\
0.159\end{array}$ & $\begin{array}{c}0.0079 \\
9 \\
0.0046 \\
0\end{array}$ & $\begin{array}{l}-0.15101 \\
-0.15439\end{array}$ & $\begin{array}{l}\text { direct effect }> \\
\text { Indirect }= \\
\text { intervene }\end{array}$ & $\begin{array}{l}\text { Farmer characteristic is not } \\
\text { an intervening variable }\end{array}$ \\
\hline 2 & $\begin{array}{l}\text { Communicatio } \\
\mathrm{n} \text { Behavior }\end{array}$ & $\begin{array}{c}- \\
0.103 \\
- \\
0.103\end{array}$ & $\begin{array}{c}0.0122 \\
4 \\
0.0070 \\
5\end{array}$ & $\begin{array}{l}-0.09076 \\
-0.09594\end{array}$ & $\begin{array}{l}\text { direct effect }> \\
\text { Indirect }= \\
\text { intervene }\end{array}$ & $\begin{array}{l}\text { Communication behavior } \\
\text { is not an intervening } \\
\text { variable }\end{array}$ \\
\hline 3 & $\begin{array}{l}\text { Business } \\
\text { Climate } \\
\text { Support }\end{array}$ & $\begin{array}{c}- \\
0.081 \\
- \\
0.081\end{array}$ & $\begin{array}{c}0.0108 \\
8 \\
0.0062 \\
7\end{array}$ & $\begin{array}{l}-0.07012 \\
-0.07472\end{array}$ & $\begin{array}{l}\text { direct effect > } \\
\text { Indirect } \\
=\text { intervene }\end{array}$ & $\begin{array}{l}\text { Business climate support } \\
\text { is not an intervening } \\
\text { variable }\end{array}$ \\
\hline
\end{tabular}

\section{Discussion}

The performance of farmer characteristic (Figure 2a and 2b) shows that most respondents are included in a productive age $(92 \%)$, low educational or primary school level $(52 \%)$, quite high family dependent (40\%), moderate cosmopolitan (40\%), and has farming business experience in a long period category above 20 years $(65 \%)$. The regression analysis shows that the farmer characteristic gives a significant influence $(\mathrm{p}<0.001)$ with a negative coefficient on the tomato farmer behavior transformation (Table 1). This result means that transforming farmer behavior should consider the farmer individual characters, mainly the farmer age, experience level, educational level, and farming business experience is unnecessary to be excessive as causing a negative influences when improved. This result follows the study of Effendy (2020) and Effendy and Badri (2020) who stated that farmer capacity is influenced by the respondent characteristics, mainly age, education, training, experience, group support, land area, and cosmopolitan level. Besides, the study result of Effendy and Sudiro (202), Prilierdi (2015) concluded that age, education, land area, and extension officer role affected the farmer participation in planning, performing, and evaluating the farming business.

Communication behavior of farmer (Figure 3) explains that the communication behavior obtained from the informal leader is in high category (35.5\%), while cooperative behavior and government program which are respectively 34.5 and $34.25 \%$, are in the low category. The regression analysis result shows that communication behavior of farmer respondent directly and significantly influences $(p<0.005)$ the tomato farmer behavior transformation (Table 1). This means that a better farmer behavior will cause a better behavior transformation in tomato farming business. This result similar to Permatasari
(2009), Effendy and Sudiro (2020) who concluded that communication line availability determined the farmer participation in farming business. Besides, Effendy (2020), Effendy and Badri (2020), Kurnia (2011) concluded that easier information access as the determined factor for youth development in business.

Farming business environment (Figure 4) shows that the production market availability belong to high category $(37 \%)$, as well as financial facility such as bank and cooperative is included in a high category (36\%). Only production input availability is included in a low category $(34.75 \%)$. The regression analysis obtains that the business environment directly and significantly influences $(p<0.005)$ the tomato farmer behavior transformation (Table 5). This condition can be interpreted that a better financial facility and production market will accelerate the farmer behavior transformation by still considering the production input availability. This result follows the study result of Effendy (2020) who concluded that an external support in the form of market for production determined the farmer capacity in planning, performing, evaluating the farming business. Effendy, Dayat, and Oktaviansyah (2020) mentioned that the existence of governmental support in the form of food plant agricultural commodity production improvement program could increase the farmer participation in planning, performing, and evaluating the farming business.

The farmer perception on extension (Figure 5) explains that majority of farmers $(38.5 \%)$ argue that the extension material is included in a high category, as well as extension media (35.5\%), however extension officer role and method used (34 and 33.5\%, respectively) are still included in a low category. The regression analysis obtains that farmer perception on extension directly and significantly influences $(p<0.005)$ the tomato farmer behavior transformation (Table 5). This means that the extension material and media determine the farmer 
ISSN 2201-2796

behavior transformation, thus the materials presented to farmers in an extension activity should be based on the requirement or problems found, as well as media used should possibly be based on the resource availability or region local wisdom. This result supports the study result of Effendy and Gumelar (2020) who concluded that the extension officer role and media used significantly influenced the innovation adoption especially the organic fertilizer.

The innovation characteristic (Figure 6) reveals that majority of respondents $(37 \%)$ separates the relative advantage to included in a high category, as well as the complexity level $(35.75 \%)$. The regression analysis result obtains that the innovation characteristic gives a direct and significant effect $(p<0.005)$ on the tomato farmer behavior transformation (Table 5). This result can be interpreted that advantage given factor and simplicity level of an innovation becomes the main consideration in taking a decision either to accept or deny this innovation. This result follows the study result of Effendy and Haryanto (2020) who concluded that the innovation attribute specifically the relative advantage obtained and hardness level of an innovation became the farmer main consideration to accept this innovation or not.
Based on the explanation above, it can be concluded that the farmer characteristics and communication behavior have negative influences on the tomato farmer behavior transformation into a better farming business. Apart from the business environment, the farmer perception against extension and innovation characteristics have significant and positive on the tomato farmer behavior transformation.

\section{Tomato Farmer Behavior Transformation Model}

Based on the explanation above (Table 7 and 8), it can be concluded that the tomato farmer behavior transformation (Y) is negatively and directly influenced by the farming business environment $\left(\mathrm{X}_{3}\right)$, while positively and directly influenced by farmer perception on extension $\left(\mathrm{X}_{4}\right)$, and innovation characteristics $\left(\mathrm{X}_{5}\right)$. The farmer behavior transformation (Y) is also indirectly influenced by the respondent characteristics $\left(\mathrm{X}_{1}\right)$ through farmer perception on extension $\left(\mathrm{X}_{4}\right)$ and innovation characteristics $\left(\mathrm{X}_{5}\right)$. Furthermore, the farmer behavior transformation $(\mathrm{Y})$ is also indirectly influenced by farming business environment $\left(\mathrm{X}_{3}\right)$ through farmer perception on extension $\left(\mathrm{X}_{4}\right)$ and innovation characteristics $\left(\mathrm{X}_{5}\right)$ as presented on Figure 3.

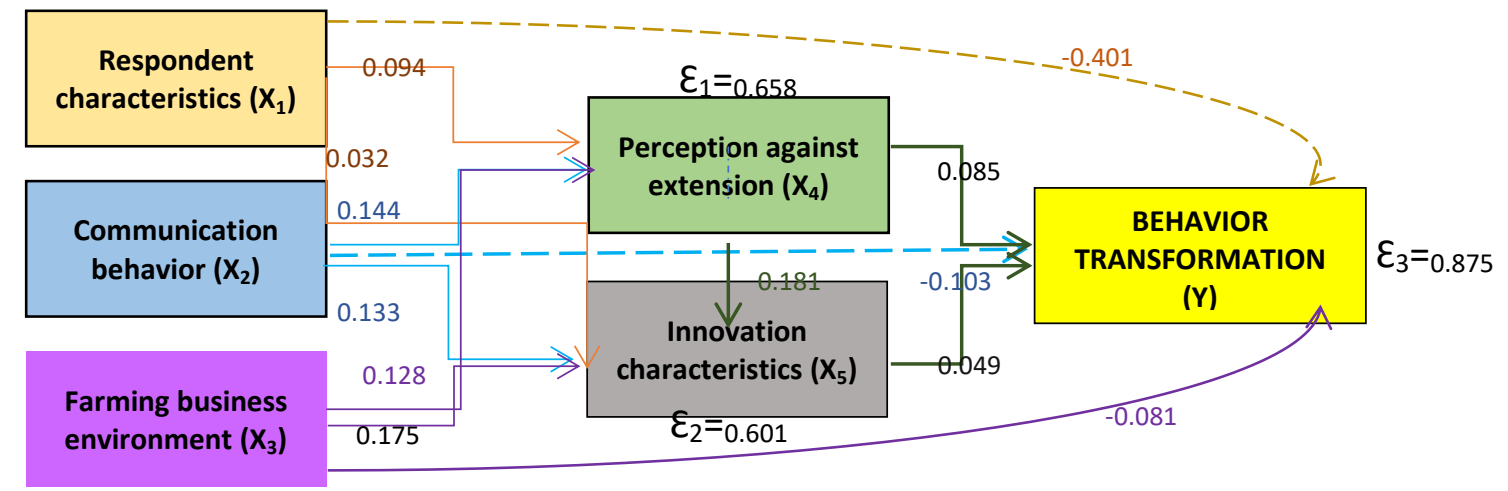

Figure 8. Farmer Behavior Transformation Model

Based on Figure 8, it can be formulated a strategy to improve the tomato farmer behavior transformation, starting from providing a farmer understanding by extension program, therefore farmers will be more attracted to the materials, media, and methods based on the farmer requirements or problems. The innovation characteristics should be considered as extension materials in using the production input, productivity improvement, and plant variety selection. Negative factors such as business environment (financial facility, marketing, and production input availability) should be kept and maintained well, therefore untriggering the contra-productive. Furthermore, the respondent individual characteristics especially age majority in the productive range and farming business experience in a long-term period can be an asset as a learning source in the innovation spreading diffussion process on the environment. Although there are some positive conditions that can trigger the tomato farmer behavior transformation, low educational factor, narrow land area, and sufficient cosmopolitan level becomes the problems on the tomato farmer behavior transformation.

\section{CONCLUSION}

The conclusions of the study were: (1) most of the respondents $(66.36 \%)$ were included in the moderate category of changing the behavior of the application of tomato farming in Megamendung District, (2) perceptions of counseling, innovation characteristics, and the environment or business climate had a direct and real effect on behavior transformation. Tomato farmers, while individual respondent characteristics and communication behavior have a significant indirect effect, (3) farmers' 
perceptions of extension services and innovation characteristics are intermediate variables so that they can trigger individual characteristics, petni communication behavior and business climate to increase the transformation of tomato farmer behavior, (4) strategy to accelerate changes in farmer behavior, it starts with providing understanding to farmers about extension so that farmers are more interested in materials, media, and methods that suit their needs or problems. The characteristics of innovation should be of concern as extension materials, especially in the use of production facilities, increasing productivity, and selecting plant varieties. Factors that have a negative impact, such as the business environment (availability of financial facilities, marketing, and production facilities) must be properly maintained and managed, so as not to encourage being counterproductive.

\section{RECOMMENDATION}

The tomato farmer behavior transformation can be accelerated by providing the farmer understanding through extension, therefore the farmers will be more attracted to materials, media, and methods based on the farmer requirements or problems. The innovation characteristics should be considered as an extension material especially in using the production input, productivity improvement, and plant variety selection. Negative factors such as business environment (financial facility, marketing, and production input availability) should be kept and maintained well, therefore untriggering the contra-productive.

\section{ACKNOWLEDGEMENTS}

By finishing this study, authours would like to thank the director of Bogor Agricultural Development Polytechnique for giving the support and opportunity. Also for Tedo Chandraharis, who assisted this study, as well as colleagues for giving many supports, we do hope you receive gifts from Allah subhanallah wata'allah. Aamiin.

\section{REFERENCES}

(1) Adi, F. 2005. Pengembangan Partisipasi dan Penguatan Kapasitas Masyarakat,Bandung:Humaniora.

(2) [BPS] Badan Pusat Statistik. 2020. Bogor Dalam Angka 2020. Bogor: BPSKabupaten Bogor.

(3) $[\mathrm{BPP}]$ Balai Penyuluhan Petanian. 2019. Programa Profil BPP Wilayah VII CiawiKecamatan Megamendung 2019.

(4) Effendy, L. 2014. Bahan Ajar Merancang Pengkajian Penyuluhan. STPP Bogor. $40 \mathrm{Hal}$.

(5) Effendy, L, Pradiana W, Rahmawati R. 2020. The Model of Rural YouthEmpowerment through Red Chili Farming in Sindangkasih Sub-district ofCiamis, Indonesia.The International Journal of Science \& Technoledge. $\quad$ Vol. 8 (6), No. 9 - 15.Juni 2020.p: 9 - 15

(6) Effendy, L., Badri, D. 2019. The farmer capacity improvement model on theimplementation of rice field balanced fertilization in Sindangkasihsubdistrict Ciamis. Journal of the Social Sciences. Volume 42 Number2. April 2020. p: 1769 - 1780

(7) Effendy, L. Sudiro. 2020. Models to Increase the Farmers' Participation onthe Implementation of Lowland Rice Balanced Fertilization in Cikoneng Subdistrict Ciamis. International Journal of Arts and Social Science.Volume 3 (1), January-February 2020. p: 43 - 53

(8) Effendy, L. 2020. The Role of Institution and Innovation Attributes in theAdoption of Integrated Crop Management Technology of Lowland Rice of

West Bandung and Sumedang Districts. International Journal of Multicultural and Multireligious Understanding, Vol. 7 (4). May 2020. p:279-293.

(9) Effendy, L. Haryanto Y. 2020. Determinant Factors of Rural YouthParticipation in Agricultural Development Programme at MajalengkaDistrict, Indonesia. International Journal of Innovative Research \&Development. Vol. 9 (5). May 2020. p: 1 10

(10) Effendy, L.\& Gumelar F. 2019. Adoption Level of the Use of OrganicFertilizer for Lowland Rice in Cikoneng Subdistrict Ciamis. International Journal of Science and Research (IJSR).Vol.9(4). April 2020. p: 317-322

(11) Effendy, Lukman, Mustofa R. 2020. Model Pengembangan Kelembagaan Petani MenujuKelembagaan Ekonomi Petani di Kecamatan Sindangkasih Ciamis. Jurnal Ekonomi

Pembangunan Vol.6.No.1 38 - 47. Juni 2020. p: 38 47

(12) Effendy, L. Dayat, Oktaviansyah. 2020. A Model of Farmers' Participation Improvement in the Use of Novel High-Yielding Variety of Lowland Rice in Sindangkasih Subdistrict Ciamis West Java, Indonesia.Journal of the Social Sciences. Volume 42 Number 3. Juli 2020. 1949 - 1958

(13) Emzir, 2010. Metedologi Penelitian Kualitatif (Analisis Data), Jakarta:PT RajaGrafindo Persada.

(14) Permatasari B. 2009. Hubungan Perilaku Kepemimpinan dengan DinamikKelompok dan Tingkat Adopsi Inovasi Pupuk Organik Cair pada Budidaya Tanaman Cabai di Kecamatan Candipuro Kabupaten LampungSelatan. Skripsi. Jurusan Sosial Ekonomi Pertanian. Fakultas PertanianUniversitas Lampung.

(15) Prilierdi Ayogi. 2015. Relationship between farmer's characteristic and Watermelon (Citrullus vulgaris) in the Sugih Waras village Muara Sugihan District Banyuasin Regancy. ISSN 2301-4181 Societa IV-1:27 -32, Juni. Fakultas Pertanian Universitas Muhammadiyah Palembang.

(16) Rusidi. 1978. Dinamika Kelompok Tani Dalam Mencapai Tujuannya. Tesis.Fakultas Pertanian IPB Bogor

(17) Suci Kurnia. 2011. Effects of Extension to Farmers' Decisionin AdoptingIntegrated Farming Technology. Jurnal Agro Ekonomi, Volume 29 No.1,Mei: 1-24. Pusat Sosial Ekonomi dan Kebijakan Pertanian. Bogor. 
(18) Umar H. 2001. Metode Penelitian untuk Skripsi dan Thesis Bisnis. Jakarta: PT Raja Grafindo Persada

(19) Yunasaf U. 2007. Kepemimpinan Ketua Kelompok Dan Hubungannya DenganKeefektifan Kelompok
(Kasus Pada Kelompok Tani Ternak Sapi Perah DiWilayah Kerja Koperasi Serba Usaha Tandangsari Sumedang). Jurnal Ilmu Ternak Vol. 07, No. 02, Halaman 179-185. Universitas Padjajaran. 